УДК 06.08:65.012.32

DOI: https://doi.org/10.37320/2415-3583/11.19

Вартанова О.B.

доктор економічних наук, професор,

Черкаський державний технологічний університет ORCID: https://orcid.org/0000-0002-8706-6437

\title{
ІДЕНТИФІКАЦІЯ РЕСУРСІВ ЗНАНЬ ЗАКЛАДІВ ВИЩОЇ ОСВІТИ НА ОСНОВІ ІНФОРМАЦІЙНО-КОГНІТИВНИХ ТЕХНОЛОГІЙ
}

У статті обтрунтовано необхідність ідентифікації ресурсів знань закладів вищої освіти, а саме визначення носїв, форм, локалізаиї та напрямів руху знань. Наголошено на тому, що рух знань закладу вищої освіти відбувається впорядковано та утворює ичикл знань. Розглянуто структуру простору руху знань, згідно з чим знання класифікуються за рівнем кодифікаиії та дифузії. Обтрунтовано необхідність застосування інформаційно-когнітивних технологій в управлінні знаннями закладів вищої освіти, організації стратегічних (експертних) сесій. Запропоновано процедуру ідентифікації ресурсів знань закладу вищої освіти, яка трунтується на виявленні джерел знань, які спроможні забезпечити конкурентні переваги закладу вищої освіти; запропоновано методичний інструментарій такої ідентифікаиії. Побудовано матрицю ресурсів знань закладу вищоӧ освіти на основі комбінування регуляторних, позиційних, функціональних та організаџійних спроможностей, а також визначено прогалини знань закладу вищої освіти.

Ключові слова: заклад вищяої освіти, знання, ідентифікація, інформаційно-когнітивні технології, ресурси знань, рух знань, циикл знань.

Постановка проблеми. Просто зараз у світі відбувається перехід до нового, шостого, технологічного укладу, ознаками якого є не лише виникнення принципово нових технологій або нових способів конструювання матеріалів та організмів, але й поява нової філософії, нового підходу до виконання завдань. Відповідно, це приводить до формування нових посткапіталістичних цінностей, а саме вартість все більшої кількості товарів та послуг стає залежною від когнітивного капіталу, отримання прибутку від інтелектуального капіталу заміщується іншими мотивами, поширення інформаційних, комунікаційних та когнітивних технологій приводить до формування мереж, які створюють більше цінностей для індивідів, мотивами для роботи стає отримання задоволення, а розмитий баланс між роботою та дозвіллям набуває нових інституційних форм. За таких умов функціонування складних соціально-економічних систем, до яких належать заклади вищої освіти, залежить від можливості й здатності останніх генерувати новий інтелектуальний продукт, здобувати та створювати нові знання, які стають конкурентними перевагами у XXI столітті. Реалії часу змушують вирішувати багато завдань одночасно, а саме генерувати нові технології та знання, ефективно перетворювати й передавати знання, впроваджувати нові інформаційно-когнітивні технології здобування знань. Завдання ідентифікації ресурсів знань на основі інформаційнокогнітивних технологій перебуває в площині виявлення персоніфікованих та корпоративних знань, а також способів перетворення персоніфікованого знання на корпоративне.
Аналіз останніх досліджень і публікацій. Теоретичні засади управління знаннями та функціонування економіки знань знайшли відображення в наукових роботах відомих учених, таких Г. Гольдштейн, О. Гапоненко, О. Гребешкова, В. Верба, К. Ендрюс, І. Нонака, К. Прахальд, Г. Хемель [1], Дж. Тідд [2], В.І. Отенко, П. Селзник. Окремі аспекти діяльності закладів вищої знань викладені в роботах таких науковців, як Д. Загірняк [3], М. Боровік [4], І. Каленюк, М. Мартиненко, Г. Назарова, Л. Семів, Л. Щаульська, Л. Янковська. Теоретичний концепт дослідження циклу знань та процесів руху знань всередині підприємства створив М. Боїсот [5]. Вивчення теоретичних та емпіричних надбань цих авторів дає змогу стверджувати, що проблеми ідентифікації ресурсів знань закладів вищої освіти на основі застосування інформаційно-когнітивних технологій досі залишаються невирішеними й потребують свого розв'язання.

Мета статті. Дослідження теоретичного та емпіричного підгрунтя ідентифікації ресурсів знань закладів вищої освіти на основі інформаційно-когнітивних технологій дає змогу стверджувати, що термінологічний зміст, розуміння доцільності, практичне застосування ідентифікації знань закладів вищої освіти досі залишаються невизначеними. На нашу думку, це пов'язане, зокрема, з відсутністю стратегічного підходу до розвитку закладів вищої освіти в Україні та необхідністю ситуативного вирішення проблем, що виникають в умовах невизначеності та великої кількості зовнішніх викликів. Саме тому знання, як Т. Андрусенко, О. Востряков, Т. Гаврилова, освіти, зокрема, в контексті розвитку економіки 
а також їх носії, які цінуються в усьому світі, не вважаються цінними ресурсами в нашій країні. Отже, метою статті є ідентифікації ресурсів знань в управлінні знаннями закладів вищої освіти на основі застосування інформаційно-когнітивних технологій. Досягнення поставленої мети передбачає вирішення таких завдань:

- концептуалізація циклу знань як простору генерації, руху, перетворення й передавання знань;

- визначення інформаційно-когнітивних технологій в управлінні знаннями закладів вищої освіти;

- ідентифікація ключових знань та їх носіїв, які створюють підгрунтя для конкурентних переваг закладу вищої освіти.

Виклад основного матеріалу. Управління знаннями у своєму найбільш загальному розумінні можна визначити як сукупність процесів генерування, здобування, трансформації, передавання й контекстуалізованого використання знань (рис. 1). Ці процеси відбуваються не хаотично, а в певному порядку, їх рух утворює цикл знань.

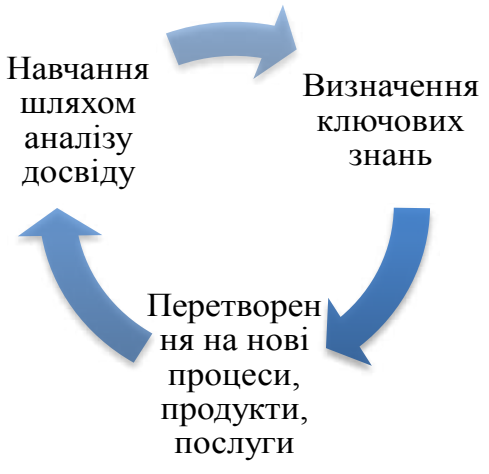

\section{Рисунок 1 - Цикл знань}

Аналіз елементів циклу знань та зв'язків між ними дає змогу ідентифікувати ресурси знань, визначити шляхи перетворення їх на нові процеси, продукти й послуги, а також встановити напрями організаційного навчання задля формалізації та контекстуалізованого використання знань для забезпечення конкурентних переваг закладів вищої освіти. 3 огляду на теоретичний конструкт циклу знань ресурси знань генеруються персоналом, перетворюються на нові процеси й послуги, а також є результатом «корпоративного навчання». Переваги такого підходу до аналізу знань чітко визначають Г. Хемель і К. Прахальд, які помістили знання, спроможності та компетенції в основу корпоративної стратегії. Загалом вони стверджують, що сталу конкурентну перевагу формують не продукти, а ключові компетенції (реальні джерела переваги повинні бути знайдені в здатності менеджменту поєднувати загальнокорпоративні технології і знання в спроможності, які дають змогу компаніям швидко адаптуватися до змін [1]); ключові спроможності втілюються більш ніж в одному продукті та можуть створювати конкурентні переваги; лідерство компаній може формуватися на основі п'яти-шести фундаментальних компетенцій. Компанія, яка складає список 20-30 компетенцій, ймовірно, не виробила список своїх основних спроможностей [1]. Звідси випливає розуміння ключової компетенції як взаємопов'язаної групи або скупчення ресурсів, знань і навичок, які є чимось набагато більшим, ніж просто організаційними «силами» або «слабкостями». Г. Хемель і К. Прахальд пропонують три характерні ознаки компетенції: вона збільшує вартість кінцевого продукту; може бути застосована відносно різних ринків; їі важко розвивати і копіювати [1]. Використання знань, спроможностей і компетенцій компанії залежить від іiі стратегічної архітектури, що отримала таке визначення: карта майбутнього, яка показує основні можливості стратегічного бачення й етапи формування спроможностей, а також здійснює справедливий розподіл ресурсів.

Компетенція закладу вищої освіти - це унікальна сукупність знань, навичок, досвіду та організаційних зв'язків, які разом з ресурсами й технологіями створюють конкурентні переваги закладу вищої освіти та забезпечують його ринковий успіх. Компетенція закладів вищої освіти втілюється в нових продуктах, процесах, освітніх i наукових послугах 3 новими споживчими властивостями. В основі компетенції завжди лежать ресурси знань.

Отже, знання, спроможності й компетенції трансформуються у стратегічні активи компанії та $є$ результатом аналізу попереднього досвіду й навчання. В циклі знань одним 3 найбільш відповідальних етапів є процес ідентифікації ресурсів знань. Його складність зумовлена самою природою знань, які часто мають неявну форму, необхідністю формалізації знань, отримання знань з їх носіїв. Підвищити ефективність процесу ідентифікації ресурсів знань можна завдяки застосуванню інформаційно-когнітивних технологій.

Для ідентифікації ресурсів знань закладів вищої освіти можуть застосовуватися метод експертних оцінок, бальний метод, індивідуальні та групові методи здобування знань, експертні сесії, шкалювання, метод ранжирування, метод побудови профілів, інтегральні показники. Як один 3 найбільш результативних ми вибрали метод експертних сесій, а саме організацію експертних сесій. Він дає змогу використати теоретичну конструкцію руху знань всередині циклу знань (рис. 2) для ідентифікації ресурсів знань закладів вищої освіти. Завданнями організації експертних сесії є:

- визначення носіїв персоніфікованих і корпоративних знань закладу вищої освіти на основі аналізу знань та їх руху; 
- виявлення місць локалізації знань, «сліпі плями» у їх формуванні;

- класифікація знань 3ВО та визначення рівня їх унікальності;

- визначення напрямів руху знань в циклі знань та організаційних зв'язків всередині 3ВО;
- визначення знань, які здатні створити ключову компетенцію ЗВО та стати основою формування конкурентних переваг.

Для ідентифікації ресурсів знань закладу вищої освіти використано «метод 635» (різновид мозкового штурму), особливостями якого є такі:

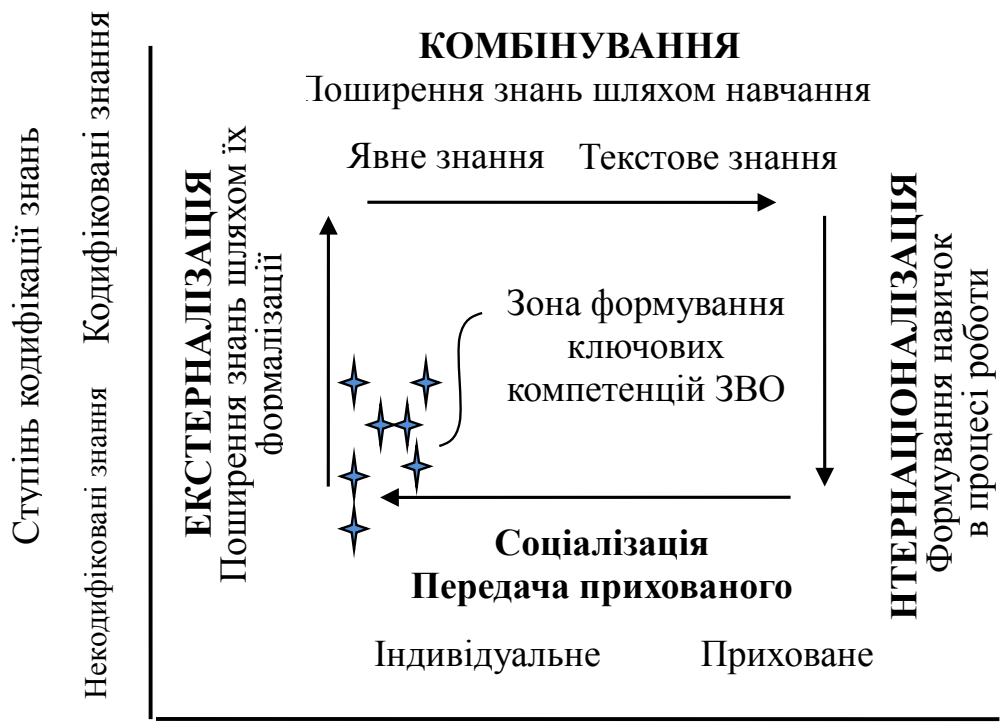

Непоширені знання Поширені знання

Ступінь поширення знань (дифузія)

Рисунок 2 - Теоретична конструкція циклу знань

Джерело: сформовано на основі [5]

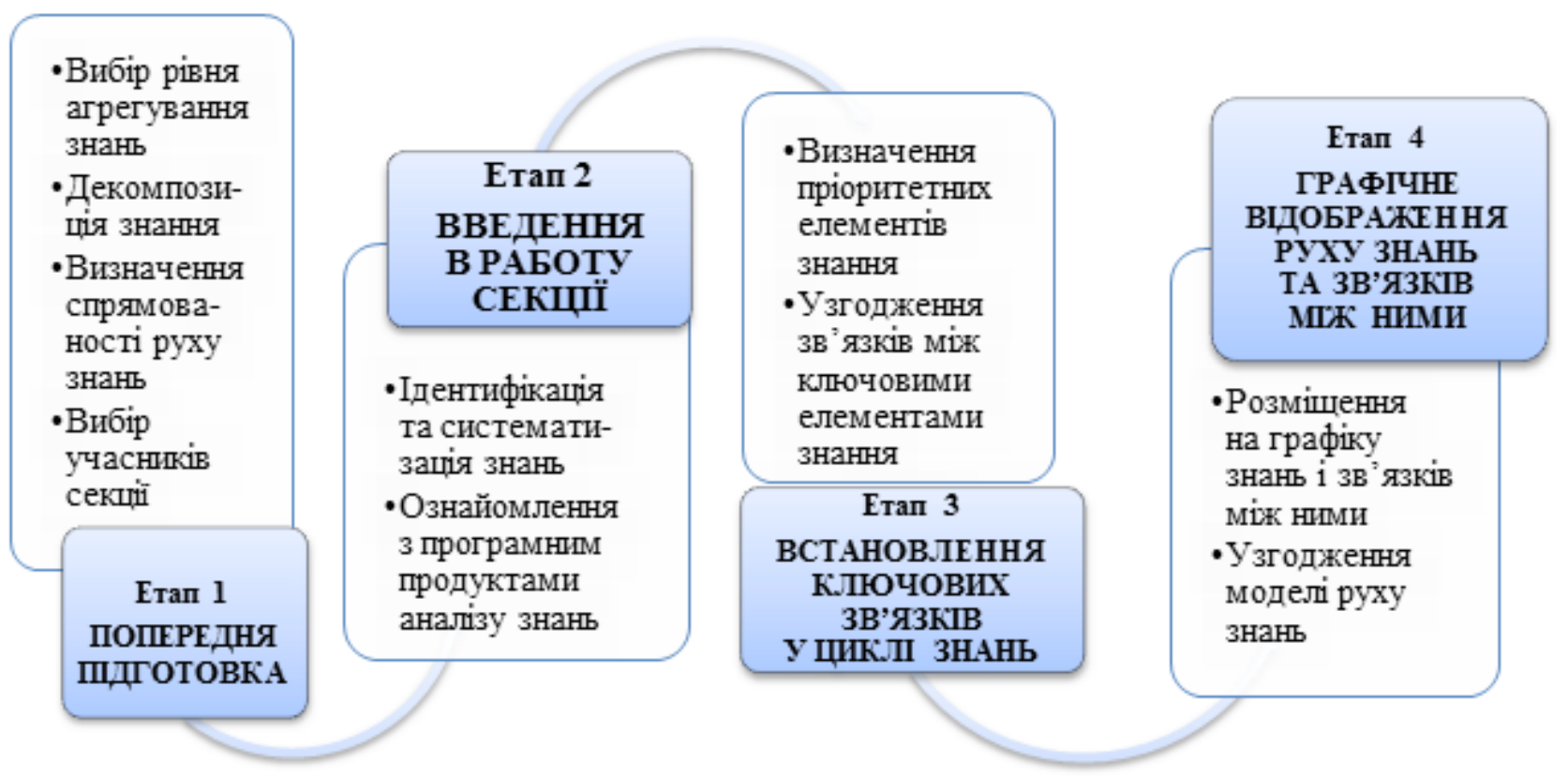

Рисунок 3 - Процедура ідентифікації ресурсів знань закладів вищої освіти на основі аналізу руху знань у циклі знань

Джерело: складено автором 
- збирається група з шести учасників, яка спочатку аналізує й чітко формулює проблему;

- кожен учасник заносить у формуляр три пропозиції щодо вирішення проблеми, на що відводиться п’ять хвилин;

- згодом кожен учасник передає свій формуляр сусідові;

- останній учасник бере до уваги пропозиції свого попередника, а під ними в трьох полях вносить ще три власні пропозиції; ці пропозиції можуть уже існувати в подальшому (асоціативному) розробленні записаних рішень, але можуть бути висунуті абсолютно нові пропозиції;

- через п'ять хвилин кожен учасник знову передає свій нинішній формуляр в тому ж напрямку, процес завершується, коли кожен учасник обробив кожен формуляр.

Процедура ідентифікації ресурсів знань на основі інформаційно-когнітивних технологій шляхом аналізу руху знань в циклі знань подана на рис. 3.

Відповідно до концептуальних положень руху знань у циклі знань він здійснюється за двома напрямами, такими як кодифікація, тобто ступінь, до якого інформація може бути стиснутою й вираженою у явній формі (формалізація знань); дифузія, тобто ступінь поширення інформації між певною кількістю агентів. Теорія М. Боїсота описує умови, за яких нові знання можуть бути структуровані й поширені як всередині компанії, так і між ними, а також дає змогу інтегрувати їх у модель корпоративного навчання. Як видно 3 рис. 2, знання, які мають відносно низькі значення кодифікації та дифузії, можуть утворювати ключову компетенцію закладу вищої освіти й забезпечувати його конкурентні переваги. Застосування запропонованих технологій ідентифікації ресурсів знань

Таблиця 1 - Матриця ресурсів знань, які формують ключову компетенцію закладу вищої освіти

\begin{tabular}{|c|c|c|c|}
\hline \multicolumn{4}{|c|}{ Ресурси знань закладу вищої освіти } \\
\hline $\begin{array}{l}\text { Регуляторні } \\
\text { спроможності }\end{array}$ & Позиційні спроможності & & $\begin{array}{c}\text { Динамічні } \\
\text { спроможності }\end{array}$ \\
\hline \multicolumn{4}{|c|}{ Черкаський державний технічний університет } \\
\hline $\begin{array}{l}\text { 1) Нематеріальні активи } \\
\text { (права інтелектуальної } \\
\text { власності на наукові та } \\
\text { методичні розробки); } \\
\text { 2) науковий потенціал, } \\
\text { який дає змогу } \\
\text { реалізовувати міжнародні } \\
\text { наукові проєкти; } \\
\text { 3) наявність сучасних } \\
\text { освітніх програм, зокрема } \\
\text { в галузі технічних наук; } \\
\text { 4) створення сприятливого } \\
\text { освітнього середовища } \\
\text { для здобувачів освітніх } \\
\text { послуг (організація } \\
\text { навчального процесу, } \\
\text { участь у спеціальних } \\
\text { наукових заходах, } \\
\text { створення системи } \\
\text { стимулів для підвищення } \\
\text { якості навчання); } \\
\text { 5) функціональна } \\
\text { спеціалізація ЗВО }\end{array}$ & $\begin{array}{l}\text { 1) Бренд ЗВО як сучасного } \\
\text { освітньо-наукового простору; } \\
\text { 2) репутація університету як } \\
\text { потужного закладу вищої освіти } \\
\text { в регіоні; } \\
\text { 3) репутація окремих носіїв } \\
\text { знань, іх професійні компетенцї; } \\
\text { 4) корпоративна мережа знань; } \\
\text { 5) персоніфіковані знання } \\
\text { персоналу університету; } \\
\text { 6) система корпоративного } \\
\text { та зовнішнього навчання } \\
\text { (міжнародні проєкти, } \\
\text { стажування, підвищення } \\
\text { кваліфікації, тренінги); } \\
\text { 7) налагоджена та ефективна } \\
\text { система дистанційної освіти; } \\
\text { 8) ефективні організаційні } \\
\text { зв’язки, які дають змогу } \\
\text { швидко реалізувати зовнішні та } \\
\text { внутрішні можливості шляхом } \\
\text { мобілізації ресурсів і узгодження } \\
\text { роботи персоналу. }\end{array}$ & $\begin{array}{l}\text { 1) Забезпечення } \\
\text { високої якості вищої } \\
\text { освіти завдяки } \\
\text { дотриманню зовнішніх } \\
\text { та внутрішніх } \\
\text { стандартів; } \\
\text { 2) ефективна система } \\
\text { просування освітніх } \\
\text { послуг; } \\
\text { 3) ефективна } \\
\text { система комунікації } \\
\text { з майбутніми } \\
\text { здобувачами вищої } \\
\text { освіти, повне } \\
\text { охоплення цільової } \\
\text { аудиторії; } \\
\text { 4) сильний кадровий } \\
\text { склад, узгоджена } \\
\text { робота підрозділів; } \\
\text { 5) “kпош-һоw” } \\
\text { співробітників; } \\
\text { 6) потужний кадровий } \\
\text { склад. }\end{array}$ & $\begin{array}{l}\text { 1) Висока споживча } \\
\text { цінність продукту; } \\
\text { 2) розвиток } \\
\text { внутрішніх процесів } \\
\text { та організаційних } \\
\text { зв’язків, що сприяє } \\
\text { більш швидкій } \\
\text { адаптації до змін } \\
\text { зовнішнього } \\
\text { середовища; } \\
\text { 3) дотримання } \\
\text { стандартів якості } \\
\text { вищої освіти; } \\
\text { 4) спроможність } \\
\text { управління змінами; } \\
\text { 5) здатність до } \\
\text { інновацій; } \\
\text { 6) розвиток персоналу. }\end{array}$ \\
\hline $\begin{array}{l}\text { Прогалини знань } \\
\text { закладу вищої освіти } \\
\text { (слабкі місця управління } \\
\text { знаннями) }\end{array}$ & \multicolumn{3}{|c|}{$\begin{array}{l}\text { Наявність потужного конкурента, якого можна порівняти за розміром та бізнес- } \\
\text { моделлю, але який має більш високий офіційний статус. Висока конкуренція } \\
\text { збільш потужними ЗВО України та зарубіжними ЗВО. Більш високі рейтингові } \\
\text { показники конкурента завдяки здійсненню фундаментальної науки. Копіювання } \\
\text { певних інноваційних рішень та підходів з боку основного конкурента. Внутрішнє } \\
\text { суперництво між підрозділами. Слабкі стимули інноваційної активності. Слабкий } \\
\text { рівень знань здобувачів вищої освіти. Несприятлива демографічна ситуація на } \\
\text { ринку освітніх послуг. }\end{array}$} \\
\hline
\end{tabular}

Джерело: складено автором 
закладу вищої освіти дало змогу побудувати матрицю його ресурсів знань (табл. 1).

Висновки. Дослідження методів i технологій ідентифікації ресурсів знань закладів вищої освіти дало змогу зробити такі висновки:

1) Управління знаннями у своєму найбільш загальному розумінні можна визначити як сукупність процесів генерування, здобування, трансформації, передавання та контекстуалізованого використання знань. Ці процеси відбуваються не хаотично, а в певному порядку, їх рух утворює цикл знань.

2) Розглянуто теоретичну структуру циклу знань, який дає розуміння руху знань всередині компанії та за ії межами, а також визначає критерії знань, які мають потенціал утворення ключової компетенції закладу вищої освіти та його конкурентних переваг.

3) Під компетенцією закладів вищої освіти розуміється як унікальна сукупність знань, навичок, досвіду та організаційних зв'язків, які разом 3 ресурсами й технологіями створюють конку- рентні переваги закладу вищої освіти й забезпечують його ринковий успіх. Компетенція закладів вищої освіти втілюється в нових продуктах, процесах, освітніх і наукових послугах з новими споживчими властивостями. В основі компетенції завжди лежать ресурси знань.

4) Встановлено, що одним 3 найефективніших способів ідентифікаціі ресурсів знань закладу вищої освіти є організація стратегічних (експертних) сесій, тому автором запропонована процедура ідентифікації ресурсів знань закладу вищої освіти, яка грунтується на виявленні всіх джерел знань, їх носіїв, локалізації, які спроможні забезпечити конкурентні переваги закладу вищої освіти, а також запропоновано методичний інструментарій такої ідентифікації.

5) Побудовано матрицю ресурсів знань закладів вищої освіти на основі комбінування регуляторних, позиційних, функціональних та організаційних спроможностей та визначено прогалини знань закладу вищої освіти.

\section{Список використаних джерел:}

1. Prahalad C.K., Hamel G. The core competence of the corporation. Harvard Business Review. 1990. Vol. 68. No. 3. P. 79-91.

2. Tidd J. From strategic management to strategic competence: Measuring technological, Market and Organization Innovation. 2nd Edition. London : Imperial College Press, 2006. 437 p.

3. Загірняк Д. Послуги вищої освіти: структура пропозиції та рівень конкуренції. Економіка $i$ право. 2018. № 1 (49). С. 105-116.

4. Боровик М. Управління інформаційно-комунікаційним забезпеченням сталого розвитку закладів вищої освіти на засадах економіки знань: теорія та методологія : монографія. Харків : Друкарня Мадрид, 2019. 440 с.

5. Boisot M. Is your firm a creative destroyer? Competitive learning and knowledge flows in the technological strategic of firms. Research Policy. 1995. No. 24. P. 489-506.

\section{References:}

1. Prahalad C.K., Hamel G. (1990) The core competence of the corporation. Harvard Business Review, vol. 68, No. 3 , pp. 79-91.

2. Tidd J. (2006) From strategic management to strategic competence: Measuring technological, Market and Organization Innovation. 2nd Edition. London : Imperial College Press, 437 p.

3. Zahirniak D. (2018) Posluhy vyshchoi osvity: struktura propozytsii ta riven konkurentsii [Higher education services: supply structure and level of competition]. Economy and Law. 2018. № 1 (49), pp. 105-116.

4. Borovyk M. (2019) Upravlinnia informatsiino-komunikatsiinym zabezpechenniam staloho rozvytku zakladiv vyshchoi osvity na zasadakh ekonomiky znan: teoriia ta metodolohiia [Management of Information and Communication Support for Sustainable Development of Higher Education Departments on the Basis of Knowledge Economy: Theory and Methodology]: Monography. Kharkiv : Drukarnia Madryd, 2019. 440 p. (in Ukrainian).

5. Boisot M. (1995) Is your firm a creative destroyer? Competitive learning and knowledge flows in the technological strategic of firms. Research Policy, no. 24, pp. 489-506. 
Vartanova Olena

Cherkasy State Technological University

\section{IDENTIFICATION OF RESOURCES OF KNOWLEDGE OF HIGHER EDUCATION INSTITUTIONS BASED ON INFORMATION-COGNITIVE TECHNOLOGIES}

The article is devoted to the identification of knowledge resources of higher education institutions on the basis of information and cognitive technologies. The definition of knowledge management as a set of processes of generation, acquisition, transformation, transfer and contextualized use of knowledge is determination. It is noted that these processes do not occur randomly, but in a certain order. Their movement forms a cycle of knowledge. Identification of knowledge resources based on information-cognitive technologies enables to identify personalized and corporate knowledge and determine ways to transform personalized knowledge into corporative knowledge. It is emphasized that the movement of knowledge inside and outside higher education institutions is orderly and forms a knowledge cycle. The space of knowledge movement according to which knowledge is classified by the level of codification and diffusion is considered. The necessity of using information and cognitive technologies in the management of knowledge of higher education institutions is substantiated. The article presents the author's definition of the competence of higher education institutions as a unique combination of knowledge, skills, experience and organizational ties, which, combined with resources and technologies, create competitive advantages of higher education institutions and ensure its market success. A methodological toolkit for identifying the knowledge resources of a higher education institution is offered: the method of expert assessments, the point method, individual and group methods of knowledge search, expert sessions, scaling, ranking method, method of profiles, integrated indicators. A procedure for identifying the knowledge resources of a higher education institution is proposed, which is based on identifying sources of knowledge that are able to provide the competitive advantages of a higher education institution. The main result is a matrix of knowledge resources of higher education institutions based on a combination of regulatory, positional, functional and organizational capabilities and identification of gaps in the knowledge of higher education institutions.

Key words: higher education institution, knowledge, identification, information-cognitive technologies, knowledge resources, knowledge movement, knowledge cycle.

JEL classification: I2, 123. 